\title{
Association between HLA genotypes and COVID-19 susceptibility, severity and progression: a comprehensive review of the literature
}

\author{
Filippo Migliorini ${ }^{1 *} \mathbb{C}$, Ernesto Torsiello ${ }^{2}$, Filippo Spiezia ${ }^{3}$, Francesco Oliva ${ }^{2}$, Markus Tingart ${ }^{1}$ and
} Nicola Maffulli2,4,5

\begin{abstract}
The COVID-19 pandemic has markedly impacted on cultural, political, and economic structures all over the world. Several aspects of its pathogenesis and related clinical consequences have not yet been elucidated. Infection rates, as well morbidity and mortality differed within countries. It is intriguing for scientists to understand how patient genetics may influence the outcome of the condition, to clarify which aspects could be related the clinical variability of SARS-CoV-2 disease. We reviewed the studies exploring the role of human leukocyte antigens (HLA) genotypes on individual responses to SARS-CoV-2 infection and/or progression, discussing also the contribution of the immunological patterns MHC-related. In March 2021, the main online databases were accessed. All the articles that investigated the possible association between the HLA genotypes and related polymorphisms with susceptibility, severity and progression of COVID-19 were considered. Although both genetic and environmental factors are certainly expected to influence the susceptibility to or protection of individuals, the HLA and related polymorphisms can influence susceptibility, progression and severity of SARS-CoV-2 infection. The crucial role played by HLA molecules in the immune response, especially through pathogen-derived peptide presentation, and the huge molecular variability of HLA alleles in the human populations could be responsible for the different rates of infection and the different patients following COVID-19 infection.
\end{abstract}

Keywords: COVID-19, SARS-CoV-2, MHC, HLA, Genotypes, Haplotypes, Polymorphisms

\section{Background}

In December 2019 a cluster of pneumonia cases caused by an unknown etiological agent broke out in Wuhan [1]. A novel coronavirus was subsequently identified, sequenced and finally confirmed as the agent that caused the disease [2, 3]. In February 2020 the pathogen was named "Severe Acute Respiratory Syndrome

*Correspondence: migliorini.md@gmail.com

${ }^{1}$ Department of Orthopaedic and Trauma Surgery, RWTH University Hospital, Pauwelsstraße 30, 52074 Aachen, Germany

Full list of author information is available at the end of the article
Coronavirus-2" (SARS-CoV-2) by the International Classification Committee of Viruses [4]. At the same time, the associated disease was named "Coronavirus Disease 2019" (COVID-19) by the World Health Organization (WHO). COVID-19 currently represents a global pandemic with over 140 million confirmed cases and nearly 3 million deaths worldwide (updated to April 2021) [5]. One year after its appearance the infection has spread on all continents and the emergence of SARS-CoV-2 has caused one of the major public health and economic crises [6]. Considering the current situation, it would be useful to identify diagnostic and therapeutic targets, original author(s) and the source, provide a link to the Creative Commons licence, and indicate if changes were made. The images or other third party material in this article are included in the article's Creative Commons licence, unless indicated otherwise in a credit line to the material. If material is not included in the article's Creative Commons licence and your intended use is not permitted by statutory regulation or exceeds the permitted use, you will need to obtain permission directly from the copyright holder. To view a copy of this licence, visit http://creativecommons.org/licenses/by/4.0/. The Creative Commons Public Domain Dedication waiver (http://creativeco mmons.org/publicdomain/zero/1.0/) applies to the data made available in this article, unless otherwise stated in a credit line to the data. 
as well reliable predictors, to counter this pandemic. In this context, the role of the Human Leukocyte Antigens (HLA) complex appears particularly interesting, since its genetic variability is directly associated with individual variations in the immune response against pathogens and susceptibility to infectious diseases [7].

\section{Coronavirus}

Coronaviruses are a wide group of viruses of enveloped positive-sense single-stranded RNA [8, 9]. Various types have been described: alpha, beta, delta, and gamma, but only alpha and beta coronavirus are known to infect humans $[10,11]$. SARS-CoV-2 is a Betacoronavirus that shows many similarities $[12,13]$, including genomic $[14$, $15]$ and immune system response [16-20], to other coronaviruses [21], especially SARS-CoV and MERS-CoV [22-25]. Given the genomic similarity of SARS-CoV-2 to coronaviruses isolated in bats, the virus likely has a zoonotic origin, with bats themselves a natural reservoirs and other animals (e.g., snakes) as intermediate hosts $[26,27]$. However, currently the predominant mode of transmission is between humans, through droplets emitted with coughs and sneezes [28]. The virions structure is characterized by the nucleocapsid protein and the spike glycoprotein. The glycoprotein $\mathrm{S}$ determines the specificity of the virus for the epithelial cells of the gastrointestinal and respiratory tracts because it is able to interact with transmembrane serine protease 2 (TMPRSS2) and angiotensin converting enzyme 2 (ACE2) receptors [29, 30]. ACE2 receptors are ubiquitous and widely expressed, in particularly on the cell surface of type II pneumocytes $[31,32]$. The virus, therefore, shows high tropism for the lungs, causing fever, fatigue, cough, dyspnea, and pneumonia (CAP) [33]. Most patients present mild disease and develop an efficient immune reaction [34]. Some patients develop acute respiratory distress syndrome (ARDS), requiring intubation and mechanical ventilation (MV) in and intensive cares. Patients, often, suffer multi-organ dysfunction with high risk of death [34]. Patients over 65, particularly males, with comorbidities or organ-associated pathologies are at a higher risk of developing a severe, critical or even fatal disease course [35]. Type I diabetes mellitus has been also associated with severe clinical syndrome of SARS-CoV-2 infection. Hypertension and cardiovascular disease, obesity and/or a pro-inflammatory, and pro-coagulative state are also associated to the risk of worse outcome [36]. A dysregulated immune response participates in the sudden deterioration of COVID-19 patients, causing damage to infected and uninfected tissues. As with SARS-CoV-1 [37] and MERS-CoV [38, 39], children showed low susceptibility to the disease $[40,41]$. Infection rates seem similar to those seen in adults [42], but only $5.9 \%$ of pediatric cases were severe or critical, possibly consequent to the lower binding ability of the ACE2 receptor in children or generally higher levels of antiviral antibodies [43].

\section{HLA locus}

The human leukocyte antigen (HLA) gene complex is a locus of genes present on chromosome 6 that encodes proteins known ad major histocompatibility complexes (MHC). They constitute a specific group of molecules expressed on the cell surface, crucial for the recognition of non-self-molecules by the acquired immune system [44]. The essential function of MHCs is to bind and expose antigens derived from pathogens, to present them to the appropriate $\mathrm{T}$ lymphocytes, triggering the immune response. In particular, MHC molecules class I expose peptide antigens, present within the cytoplasm activating CD4 T-cell response [45], while MHC molecules class II expose peptide antigens present in the extracellular space activating CD8 T-cell response [46]. As HLA genes are a critical component of the antigen presentation pathway, they play a vital role in determining susceptibility to infectious disease. The HLA alleles are variable and polymorphic, and individuals with different HLA genotypes may trigger different immune responses against pathogens $[47,48]$.

\section{Materials and methods Search strategy}

The literature search of the present systematic review was conducted according this protocol:

- Patients: SARS-CoV-2 infection;

- Comparison: HLA alleles;

- Outcomes: susceptibility, severity and progression of COVID-19.

\section{Literature search}

In April 2021 the following databases were accessed: Pubmed, Embase, Scopus, Web of Science, Google Scholar. The following keywords were used in combination: coronavirus, COVID-19, SARS-CoV-2, SARS-CoV-1, MERS, infection, susceptibility, severity, progression, HLA, MHC, haplotypes, genotypes, locus, genes, alleles, polymorphisms, frequency, antigens, epitope, peptide, binder, factors, outcome, affinity, T cells, B cells, NK cells, lymphocyte, antibodies, association, correlation, genetic, pathogenesis, disease, immunology, virus, system, humoral, cellular, response, adaptive, interaction, epidemic, role, manifestation, clearance, risk, cytokines, dysregulation, affinity, clinic, injury, prognosis, diagnosis, therapy, variability, distribution, inflammatory, reaction, 
mortality, morbidity. If title and abstract matched the topic, the full-text was accessed. The bibliographies of the full-text articles were also screened for inclusion. Disagreements were solved by a third author (**). All the articles that investigate possible association between the HLA genotypes and related polymorphisms with susceptibility, severity, and progression of COVID-19 were considered. According to the authors language capabilities, articles in English, French, German, Italian, and Spanish were considered.

\section{Results}

Based on the experience gained during the previous severe acute respiratory syndrome (SARS) and middle east respiratory syndrome (MERS) epidemics, it is likely that both innate and adaptive host immunity play a role in viral clearance, disease severity and the different clinical manifestations of the disease [49-52]. Studies on the SARS-CoV-1 virus identified HLA polymorphisms associated with the disease risk in the Asian population [5358]. Also, in SARS-CoV-2 infection, different HLA alleles of the major histocompatibility complex may define individual susceptibility to infection [59].

\section{Immune system}

Recent data suggest that appropriate innate and adaptive $T$ cell-mediated humoral and cellular immune responses could help elimination of the SARS-CoV-2 virus, which in most cases coincides with clinical recovery [60]. On the other hand, an excessive cell-mediated and dysregulated innate and adaptive immune response can lead to an aggressive inflammatory reaction with the release of large amounts of pro-inflammatory cytokines. This condition, known as "cytokine storm"-resulting from the excessive production of cytokines by immune cells such as the innate dendritic cells, macrophages, natural killer (NK) cells, and the adaptive T and B cells-directly correlates with lung injury, ARDS and MOF, and leads to an unfavorable prognosis [61, 62]. Immunogenetic variation in humans could be an important target for clinical diagnosis and therapeutic intervention [63]. Binding between peptide epitopes and HLA proteins significantly contributes to cellular immune response mechanisms in human beings [64].

\section{Non-European HLA alleles}

Several studies described the pivotal role of peptides in the specificity, magnitude and quality of both humoral and cellular immune responses. In silico studies have greatly facilitated analysis of the binding affinity between all the viral peptides of SARS-CoV-2 and different HLA class I genotypes. The HLA-B*46:01 allele has a low binding affinity, suggesting that subjects with this allele may have a higher risk of developing the more severe forms of COVID-19 [65], as previously shown with SARS$\mathrm{CoV}$ [53]. On the other hand, the HLA-B*15:03 allele is reported to have the highest binding affinity for viral peptides [65]. On the contrary, the association with HLA$B^{*} 46: 01$ was not observed in the study by Yung et al., possibly because the $\mathrm{T}$ cell-mediated response could be a variable process, involving various factors, and not limited to HLA-peptide interactions [66]. However, the HLA-B22 serotype is a potential risk marker for SARSCoV-2 infection [67]. In this regard, a recent study about the HLA binders reported that five B22 alleles ( $B^{*} 54: 01$, $B * 55: 01, B * 55: 07, B * 55: 12$ and $B * 56: 01)$ were among the 94 weakest HLA-B binders to SARS-CoV-2, further suggesting B22 as a susceptibility marker [68]. The published data seem to suggest also a possible role of the HLA-B27 serotype in modulating SARS-CoV-2 infection [67]. B27 serotype mediates protection against HCV and HIV [69]. The same HLA markers may be also associated with susceptibility/resistance to all SARS-CoV-2, HIV, and HCV, may have a common general immune mechanism against viral infections. Indeed, all the three viruses are RNA viruses. In particular, SARS-CoV-2 and $\mathrm{HCV}$ are positive-sense RNA viruses, which share striking sequence and structural homology in their RNA polymerase and protease, central components for viral replication [70, 71]. Liver diseases have also been reported in COVID19 patients, more prevalently in severe cases [72]. On the other hand, lymphopenia is the clinical hallmark of HIV infection, associated with increased COVID-19 severity [73]. Altered immune homeostasis could play a role in the pathogenesis of coronavirus disease. High binding affinity between SARS-CoV-2 epitopes and the HLA-A*02:06, HLA-B*52:01, and HLA-C*12:02 alleles has been also reported. In particular, two epitopes displayed strong binding affinity for HLA-A*24:02, HLAA*02:01, and HLA-A*02:06 [74]. Unfortunately, these studies present mathematical predictions that need to be more statistically robust and better define the appropriate immunogenetic characteristics. Equally interesting is the study that reported the distribution of HLA allele frequencies in 82 Chinese individuals with COVID-19 and identified HLA-C*07:29 and HLA-B*15:27 and HLA-B as statistically significant [75]. However, in this study HLA-C*07:29 was found in one COVID-19 patient only, but in no individuals in the control group. Therefore, the significance of these findings should be interpreted with caution, and this result needs to be confirmed in studies with larger sample sizes. Another study of Chinese patients with COVID-19 reported that the HLA-A*11:01, HLA-B*51:01 and HLA-C*14:02 alleles were significantly associated with severe disease or worse outcome [76]. In another in silico analysis, the association of HLA 
gene polymorphisms with prevalence and mortality of COVID-19 was examined and a possible association between HLA-A*02:01 and an increased risk for infection were identified. This allele had a relatively lower ability to present SARS-CoV-2 antigens compared with other frequent HLA class I molecules, HLA-A*11:01 and HLA$A * 24: 02$ [77]. The HLA-A*24:02 allele was also involved in a study on bronchoalveolar lavage fluid and blood samples of COVID-19 patients [78], while the HLA-A*11:01 allele, together with the HLA-A*02:06 and HLA-B*54:01 alleles, could protect against infection [79].

\section{European HLA alleles}

In Italy, a study investigated whether specific class I HLA alleles could explain the huge differences observed for the spread of SARS-CoV-2 infection between Northern and Southern Italy. They compared HLA allele prevalence retrieved through the Italian Bone-Marrow Donor Registry with the incidence of SARS-CoV-2 infections in the different geographical regions. They showed how HLA-A*25, B*08, B*44, B*15:01, B*51, C*01, and C*03 was positively associated with the incidence of SARSCoV-2 infection, while HLA-B*14, $\mathrm{B}^{*} 18$, and $\mathrm{B}^{*} 49$ showed an inverse association. After applying a multiple regression model to eliminate confounding factors, only the HLA-C*01 and HLA-B*44 alleles, which are present with a higher frequency in the northern regions of Italy, remained positively associated with COVID-19. In addition, this was confirmed by a sub-analysis between different provinces of the same region [80]. This epidemiological analysis has made it possible to identify specific class I HLA alleles that are potentially unable to present a sufficient amount of virus-derived epitope peptides and, consequently, to trigger an adequate immune response to counteract SARS-CoV-2 infection. In this context, two individuals carrying the same antigen but different HLA profile may give rise to a completely different $\mathrm{T}$ cell-mediated immune response, since they may have completely different amounts of HLA-specific antigenderived epitopes. This hypothesis has been confirmed in several studies concerning a number of different viruses as well as tumor antigens and autoimmune models [8187]. It can be assumed that, in these patients, the virus may freely spread from the oropharyngeal mucosae, starting a more efficient replication. Consistently, both HLA-B*44 and C*01 alleles, identified as possibly permissive to SARS-CoV-2 infection in Italy, have also been associated to known inflammatory autoimmune diseases [88-92], a fact that highlights their ability to trigger non-proficient and often inappropriate immunological reactions. Interestingly, the inheritance of HLA$B * 44$ underlies susceptibility to recurrent sinopulmonary infection [93]. A further consideration stems from the knowledge that the HLA-C*01 allele, which was the most permissive to SARS-CoV-2 infection in that study, also represents the specific ligand of killer cell immunoglobulin like receptors (KIRs), KIR2DL2 and KIR2DL3 [94-96]. These receptors are able to inhibit the activity of natural killer cells, which represent the first line of host defense to the infection before the occurrence of a more specific $T$ cell response [97]. A recent report found that peptides bound to HLA-C*05:01 are recognized by one of the activating KIR (KIR2DS4) [98] and this allele was significantly associated with the risk of death from COVID-19 [99]. Again, in Italy, another study, performed in Sardinia, evaluated statistically significant association between local haplotypes and COVID-19. Almost a sanctuary throughout the human history, Sardinia could represent an ideal place to detect immunogenic factors potentially involved in resistance or susceptibility to SARS-CoV-2 infection. Overall, the analysis of the HLA alleles and haplotype frequencies showed 7 HLA alleles or haplotypes with a protective effect against SARS$\mathrm{CoV}-2$ infection, and 5 alleles or haplotypes that were associated with an increased susceptibility to infection. The most interesting alleles, after correction for multiple comparisons, were HLA-A*23:01 and HLA-DRB1*08:01. These two alleles were exclusively present in patients with a moderate or severe disease course. However, HLA-A*23:01 is an uncommon allele in the Sardinian population, and it is therefore difficult to assess its effect on the evolution of the disease. Only the HLA-A*30:02, $B^{*} 14: 02, C * 08: 02$ three-loci haplotype maintained statistically significance relation after correction of the $\mathrm{P}$ values. This haplotype strongly correlated with disease severity [100]. Again in Italy, another study identified a significant association with a higher susceptibility to the disease was found for HLA-DRB1*15:01, HLADQB1*06:02 and HLA-B*27:07 after applying the Bonferroni's correction for multiple tests [101]. The increased frequencies observed for DRB1*15:01 and DQB1*06:02 in the 99 severe affected COVID-19 Italian patients were not in line with the results obtained in a larger survey [102], which did not show any association between HLA and COVID-19, but confirmed published data [103] identifying these two alleles among seven HLA susceptibility alleles. Another interesting Italian study, through a geographic epidemiological analysis, observed that there are significant regional differences in the frequency of the two most common HLA haplotypes in the Italian population between the northern, central and southern regions, with HLA-A*01:01 g-B*08:01 g-C*07:01 g-DRB1*03:01 g (the most frequent haplotype nationwide) showing a decreasing frequency gradient, and HLA$A^{* 02: 01}$ g-B*18:01 g-C*07:01 g-DRB1*11:04 g (the second most frequent haplotype) an increasing frequency 
gradient from North to South. The geographical distribution of these haplotypes overlaps with that of COVID19 in Italy, being linearly and significantly correlated in a positive/direct way (suggestive of susceptibility) for the haplotype 1 and in a negative/inverse way (suggestive of protection) for the haplotype 2 , both for incidence and mortality [104]. In Spain, a study conducted in the ICUs of 6 hospitals in the Canary Islands found a trend to a higher infection rate of the alleles HLA-A*32, HLA-B*39 and HLA-C*16, but these $p$ values were not significant after correction for multiple comparisons. Conversely, logistic regression analysis showed that the presence of the alleles HLA-A*11, HLA-C*01, HLA-DQB1*04 were associated with higher mortality after controlling for SOFA or APACHE-II [105]. A preprint article that considers the increased risk of hospitalization as parameter suggests that HLA-A*11:01, HLA-DQA1*01:02 and HLA-C*04:01 alleles are associated with greater severity disease. This is especially evident for COVID-19 patients with HLA-C*04:01, in whom disease prognosis measured by mechanical ventilation-free days was statistically significant after Bonferroni's correction and may hold potential clinical value [106]. Regarding the different allele frequencies examined in that study, it must be emphasized that they vary greatly between regions, so it is well possible that alleles identified as risk alleles in some association studies have no weight in other populations, given their low presence in such populace [107].

\section{Conclusions}

The association between HLA and COVID-19 deserves investigations on larger patient cohorts. Only limited sets of HLA alleles have been studied. Another limitation of the studies could be that, at present, it is not possible to assess the relative importance of the HLA type in correlation to known disease-modifying risk factors such as age and clinical comorbidities [108-111]. Meanwhile, these findings may provide new insights on pathogenesis of SARS-CoV-2, the design of vaccination programs, and more effective infection control to optimize the treatment, to management of patients with the disease, to identify those at greatest risk, and to reduce morbidity and mortality. Identification of high-risk subjects susceptible to SARS-CoV-2 infection could help to prevent virus spreading, reducing public health burden and prioritizing preventive medicine. Current scientific evidence suggests to integrate HLA testing into clinical trials and combine HLA typing with COVID-19 testing to more rapidly identify a predictor of viral severity in the population, and potentially adapt vaccination strategies to genotypically at risk populations.

\section{Abbreviations}

COVID: Coronavirus disease; SARS: Severe acute respiratory syndrome; MERS: Middle east respiratory syndrome; HLA: Human leukocyte antigens; MHC: Major histocompatibility complex; S- and N-glycoprotein: Spike and nucleocapsid glycoprotein;TMPRSS2: Transmembrane serine protease 2; ACE2: Angiotensin converting enzyme 2; ARDS: Acute respiratory distress syndrome; MOF: Multiple organ failure; CAP: Community acquired pneumonia; ICU: Intensive care unit; MV: Mechanical ventilation; NK cells: Natural killer cells; CD: Cluster of differentiation; HCV: Hepatitis C virus; HIV: Human immunodeficiency virus.

\section{Acknowledgements}

None.

\section{Author's contributions}

FM: conceptualization, writing, revision, and final approval; ET: writing, revision, and final approval; FS: revision and final approval; FO: revision and final approval; MT: supervision and final approval; NM: supervision, revision, and final approval. All authors read and approved the final manuscript.

Funding

Open Access funding enabled and organized by Projekt DEAL. Not applicable.

Availability of data and materials

Not applicable.

\section{Declarations}

Ethics approval and consent to participate

Not applicable.

\section{Consent for publication}

Not applicable.

\section{Competing interests}

The authors declare that they have no competing interests.

\section{Author details}

'Department of Orthopaedic and Trauma Surgery, RWTH University Hospital, Pauwelsstraße 30, 52074 Aachen, Germany. ${ }^{2}$ Department of Medicine, Surgery and Dentistry, University of Salerno, Via S. Allende, 84081 Baronissi, SA, Italy. ${ }^{3}$ Ospedale San Carlo Potenza, Via Potito Petrone, 85100 Potenza, Italy. ${ }^{4}$ Faculty of Medicine, School of Pharmacy and Bioengineering, Keele University, Thornburrow Drive, Stoke on Trent, England. ${ }^{5}$ Barts and the London School of Medicine and Dentistry, Centre for Sports and Exercise Medicine, Mile End Hospital, Queen Mary University of London, 275 Bancroft Road, London E1 4DG, England.

Received: 21 May 2021 Accepted: 27 July 2021

Published online: 03 August 2021

\footnotetext{
References

1. Wu JT, Leung K, Bushman M, Kishore N, Niehus R, de Salazar PM, Cowling BJ, Lipsitch M, Leung GM. Addendum: estimating clinical severity of COVID-19 from the transmission dynamics in Wuhan. China Nat Med. 2020;26(7):1149-50. https://doi.org/10.1038/s41591-020-0920-6.

2. Wu YC, Chen CS, Chan YJ. The outbreak of COVID-19: an overview. J Chin Med Assoc. 2020;83(3):217-20. https://doi.org/10.1097/JCMA. 0000000000000270

3. Wu F, Zhao S, Yu B, Chen YM, Wang W, Song ZG, Hu Y, Tao ZW, Tian $J H$, Pei YY, Yuan ML, Zhang YL, Dai FH, Liu Y, Wang QM, Zheng JJ, Xu L, Holmes EC, Zhang YZ. A new coronavirus associated with human respiratory disease in China. Nature. 2020;579(7798):265-9. https://doi. org/10.1038/s41586-020-2008-3.

4. Stower H. Spread of SARS-CoV-2. Nat Med. 2020;26(4):465. https://doi. org/10.1038/s41591-020-0850-3.

5. Available online: https://covid19.who.int/.
} 
6. Lai CC, Shih TP, Ko WC, Tang HJ, Hsueh PR. Severe acute respiratory syndrome coronavirus 2 (SARS-CoV-2) and coronavirus disease-2019 (COVID-19): the epidemic and the challenges. Int J Antimicrob Agents. 2020;55(3): 105924. https://doi.org/10.1016/j.ijantimicag.2020.105924.

7. Tavasolian F, Rashidi M, Hatam GR, Jeddi M, Hosseini AZ, Mosawi SH, Abdollahi E, Inman RD. HLA, immune response, and susceptibility to COVID-19. Front Immunol. 2020;11: 601886. https://doi.org/10.3389/ fimmu.2020.601886.

8. Chen Y, Liu Q, Guo D. Emerging coronaviruses: genome structure, replication, and pathogenesis. J Med Virol. 2020;92(4):418-23. https:// doi.org/10.1002/jmv.25681.

9. Satija N, Lal SK. The molecular biology of SARS coronavirus. Ann NY Acad Sci. 2007;1 102:26-38. https://doi.org/10.1196/annals.1408.002

10. Malik YA. Properties of coronavirus and SARS-CoV-2. Malays J Pathol. 2020;42(1):3-11.

11. Yin Y, Wunderink RG. MERS, SARS and other coronaviruses as causes of pneumonia. Respirology. 2018;23(2):130-7. https://doi.org/10.1111/ resp.13196.

12. Ashour HM, Elkhatib WF, Rahman MM, Elshabrawy HA. Insights into the recent 2019 novel coronavirus (SARS-CoV-2) in light of past human coronavirus outbreaks. Pathogens. 2020;9(3):186. https://doi.org/10. 3390/pathogens9030186.

13. Yang Y, Peng F, Wang R, Yange M, Guan K, Jiang T, Xu G, Sun J, Chang C. The deadly coronaviruses: the 2003 SARS pandemic and the 2020 novel coronavirus epidemic in China. J Autoimmun. 2020;109: 102434. https://doi.org/10.1016/j.jaut.2020.102434.

14. Ceraolo C, Giorgi FM. Genomic variance of the 2019-nCoV coronavirus. J Med Virol. 2020;92(5):522-8. https://doi.org/10.1002/jmv.25700.

15. Lu R, Zhao X, Li J, Niu P, Yang B, Wu H, Wang W, Song H, Huang B, Zhu N, Bi Y, Ma X, Zhan F, Wang L, Hu T, Zhou H, Hu Z, Zhou W, Zhao L, Chen J, Meng Y, Wang J, Lin Y, Yuan J, Xie Z, Ma J, Liu WJ, Wang D, Xu W, Holmes EC, Gao GF, Wu G, Chen W, Shi W, Tan W. Genomic characterisation and epidemiology of 2019 novel coronavirus: implications for virus origins and receptor binding. Lancet. 2020;395(10224):565-74. https://doi.org/ 10.1016/S0140-6736(20)30251-8.

16. Prompetchara E, Ketloy C, Palaga T. Immune responses in COVID-19 and potential vaccines: lessons learned from SARS and MERS epidemic. Asian Pac J Allergy Immunol. 2020;38(1):1-9. https://doi.org/10.12932/ AP-200220-0772.

17. Zheng Z, Monteil VM, Maurer-Stroh S, Yew CW, Leong C, Mohd-Ismail NK, Cheyyatraivendran Arularasu S, Chow VTK, Lin RTP, Mirazimi A, Hong W, Tan YJ. Monoclonal antibodies for the S2 subunit of spike of SARS-CoV-1 cross-react with the newly-emerged SARS-CoV-2. Euro Surveill. 2020;25(28). https://doi.org/10.2807/1560-7917.ES.2020.25.28. 2000291.

18. Li G, Fan Y, Lai Y, Han T, Li Z, Zhou P, Pan P, Wang W, Hu D, Liu X, Zhang $\mathrm{Q}$, Wu J. Coronavirus infections and immune responses. J Med Virol. 2020;92(4):424-32. https://doi.org/10.1002/jmv.25685.

19. Lv H, Wu NC, Tsang OT, Yuan M, Perera R, Leung WS, So RTY, Chan JMC, Yip GK, Chik TSH, Wang Y, Choi CYC, Lin Y, Ng WW, Zhao J, Poon LLM, Peiris JSM, Wilson IA, Mok CKP. Cross-reactive antibody response between SARS-CoV-2 and SARS-CoV infections. Cell Rep. 2020;31(9): 107725. https://doi.org/10.1016/j.celrep.2020.107725.

20. Yuan M, Wu NC, Zhu X, Lee CD, So RTY, Lv H, Mok CKP, Wilson IA. A highly conserved cryptic epitope in the receptor binding domains of SARS-CoV-2 and SARS-CoV. Science. 2020;368(6491):630-3. https://doi. org/10.1126/science.abb7269.

21. Tan Y, Schneider T, Leong M, Aravind L, Zhang D. Novel immunoglobulin domain proteins provide insights into evolution and pathogenesis mechanisms of SARS-related coronaviruses. bioRxiv. 2020. https://doi. org/10.1101/2020.03.04.977736.

22. Tetro JA. Is COVID-19 receiving ADE from other coronaviruses? Microbes Infect. 2020;22(2):72-3. https://doi.org/10.1016/j.micinf.2020. 02.006 .

23. Thevarajan I, Nguyen THO, Koutsakos M, Druce J, Caly L, van de Sandt CE, Jia X, Nicholson S, Catton M, Cowie B, Tong SYC, Lewin SR, Kedzierska K. Breadth of concomitant immune responses prior to patient recovery: a case report of non-severe COVID-19. Nat Med. 2020;26(4):453-5. https://doi.org/10.1038/s41591-020-0819-2.

24. Zhu J, Kim J, Xiao X, Wang Y, Luo D, Jiang S, Chen R, Xu L, Zhang H, Moise L, Gutierrez AH, De Groot AS, Xiao G, Schoggins JW, Zhan X,
Wang T, Xie Y. The immune vulnerability landscape of the 2019 Novel Coronavirus, SARS-CoV-2. bioRxiv. 2020. https://doi.org/10.1101/2020. 02.08.939553.

25. Chen G, Wu D, Guo W, Cao Y, Huang D, Wang H, Wang T, Zhang X, Chen H, Yu H, Zhang X, Zhang M, Wu S, Song J, Chen T, Han M, Li S, Luo X, Zhao J, Ning Q. Clinical and immunological features of severe and moderate coronavirus disease 2019. J Clin Invest. 2020;130(5):2620-9. https://doi.org/10.1172/JCl137244.

26. Ahmad T, Khan M, Haroon MTH, Nasir S, Hui J, Bonilla-Aldana DK, Rodriguez-Morales AJ. COVID-19: zoonotic aspects. Travel Med Infect Dis. 2020;36: 101607. https://doi.org/10.1016/j.tmaid.2020.101607.

27. Rodriguez-Morales AJ, Bonilla-Aldana DK, Balbin-Ramon GJ, Rabaan AA, Sah R, Paniz-Mondolfi A, Pagliano P, Esposito S. History is repeating itself: probable zoonotic spillover as the cause of the 2019 novel Coronavirus Epidemic. Infez Med. 2020;28(1):3-5.

28. Karia R, Gupta I, Khandait H, Yadav A, Yadav A. COVID-19 and its modes of transmission. SN Compr Clin Med. 2020;2:1798-801. https://doi.org/ 10.1007/s42399-020-00498-4.

29. Hoffmann M, Kleine-Weber H, Schroeder S, Kruger N, Herrler T, Erichsen S, Schiergens TS, Herrler G, Wu NH, Nitsche A, Muller MA, Drosten C, Pohlmann S. SARS-CoV-2 cell entry depends on ACE2 and TMPRSS2 and is blocked by a clinically proven protease inhibitor. Cell. 2020;181 (2):271-280e278. https://doi.org/10.1016/j.cell.2020.02.052.

30. Hou Y, Zhao J, Martin W, Kallianpur A, Chung MK, Jehi L, Sharifi N, Erzurum S, Eng C, Cheng F. New insights into genetic susceptibility of COVID-19: an ACE2 and TMPRSS2 polymorphism analysis. BMC Med. 2020;18(1):216. https://doi.org/10.1186/s12916-020-01673-z.

31. Hamming I, Timens W, Bulthuis ML, Lely AT, Navis G, van Goor H. Tissue distribution of ACE2 protein, the functional receptor for SARS coronavirus. A first step in understanding SARS pathogenesis. J Pathol. 2004;203(2):631-7. https://doi.org/10.1002/path.1570.

32. Devaux CA, Rolain JM, Raoult D. ACE2 receptor polymorphism: susceptibility to SARS-CoV-2, hypertension, multi-organ failure, and COVID-19 disease outcome. J Microbiol Immunol Infect. 2020;53(3):425-35. https://doi.org/10.1016/i.jmii.2020.04.015.

33. Huang $C$, Wang $Y, L i X$, Ren L, Zhao J, Hu Y, Zhang L, Fan G, Xu J, Gu X, Cheng Z, Yu T, Xia J, Wei Y, Wu W, Xie X, Yin W, Li H, Liu M, Xiao Y, Gao H, Guo L, Xie J, Wang G, Jiang R, Gao Z, Jin Q, Wang J, Cao B. Clinical features of patients infected with 2019 novel coronavirus in Wuhan, China. Lancet. 2020;395(10223):497-506. https://doi.org/10.1016/ S0140-6736(20)30183-5.

34. Xu Z, Shi L, Wang Y, Zhang J, Huang L, Zhang C, Liu S, Zhao P, Liu H, Zhu L, Tai Y, Bai C, Gao T, Song J, Xia P, Dong J, Zhao J, Wang FS. Pathological findings of COVID-19 associated with acute respiratory distress syndrome. Lancet Respir Med. 2020;8(4):420-2. https://doi.org/10.1016/ S2213-2600(20)30076-X.

35. Zhou F, Yu T, Du R, Fan G, Liu Y, Liu Z, Xiang J, Wang Y, Song B, Gu X, Guan L, Wei Y, Li H, Wu X, Xu J, Tu S, Zhang Y, Chen H, Cao B. Clinical course and risk factors for mortality of adult inpatients with COVID-19 in Wuhan, China: a retrospective cohort study. Lancet. 2020;395(10229):1054-62. https://doi.org/10.1016/S0140-6736(20) 30566-3.

36. Apicella M, Campopiano MC, Mantuano M, Mazoni L, Coppelli A, Del Prato S. COVID-19 in people with diabetes: understanding the reasons for worse outcomes. Lancet Diabetes Endocrinol. 2020;8(9):782-92. https://doi.org/10.1016/S2213-8587(20)30238-2.

37. Denison MR. Severe acute respiratory syndrome coronavirus pathogenesis, disease and vaccines: an update. Pediatr Infect Dis J. 2004;23(11 Suppl):S207-214. https://doi.org/10.1097/01.inf.0000144666.95284.05.

38. Thabet F, Chehab M, Bafaqih H, Al Mohaimeed S. Middle East respiratory syndrome coronavirus in children. Saudi Med J. 2015;36(4):484-6. https://doi.org/10.15537/smj.2015.4.10243.

39. Al-Tawfiq JA, Kattan RF, Memish ZA. Middle East respiratory syndrome coronavirus disease is rare in children: an update from Saudi Arabia. World J Clin Pediatr. 2016;5(4):391-6. https://doi.org/10.5409/wjcp.v5.i4. 391.

40. Cao Q, Chen YC, Chen CL, Chiu CH. SARS-CoV-2 infection in children: transmission dynamics and clinical characteristics. J Formos Med Assoc. 2020;119(3):670-3. https://doi.org/10.1016/j.jfma.2020.02.009.

41. Lu X, Zhang L, Du H, Zhang J, Li YY, Qu J, Zhang W, Wang Y, Bao S, Li Y, Wu C, Liu H, Liu D, Shao J, Peng X, Yang Y, Liu Z, Xiang Y, Zhang F, Silva 
RM, Pinkerton KE, Shen K, Xiao H, Xu S, Wong GWK, Chinese Pediatric Novel Coronavirus Study T. SARS-CoV-2 infection in children. N Engl J Med. 2020;382(17):1663-5. https://doi.org/10.1056/NEJMc2005073.

42. Bi Q, Wu Y, Mei S, Ye C, Zou X, Zhang Z, Liu X, Wei L, Truelove SA, Zhang T, Gao W, Cheng C, Tang X, Wu X, Wu Y, Sun B, Huang S, Sun $Y$, Zhang J, Ma T, Lessler J, Feng T. Epidemiology and transmission of COVID-19 in 391 cases and 1286 of their close contacts in Shenzhen, China: a retrospective cohort study. Lancet Infect Dis. 2020;20(8):911-9. https://doi.org/10.1016/S1473-3099(20)30287-5.

43. Dong Y, Mo X, Hu Y, Qi X, Jiang F, Jiang Z, Tong S. Epidemiology of COVID-19 among children in China. Pediatrics. 2020;145(6):e20200702. https://doi.org/10.1542/peds.2020-0702.

44. Kulski JK, Shiina T, Dijkstra JM. Genomic diversity of the major histocompatibility complex in health and disease. Cells. 2019;8(10):1270. https://doi.org/10.3390/cells8101270.

45. Ambagala AP, Solheim JC, Srikumaran S. Viral interference with $\mathrm{MHC}$ class I antigen presentation pathway: the battle continues. Vet Immunol Immunopathol. 2005;107(1-2):1-15. https://doi.org/10. 1016/j.vetimm.2005.04.006.

46. Yewdell JW, Hill AB. Viral interference with antigen presentation. Nat Immunol. 2002;3(11):1019-25. https://doi.org/10.1038/ni1102-1019.

47. Apanius V, Penn D, Slev PR, Ruff LR, Potts WK. The nature of selection on the major histocompatibility complex. Crit Rev Immunol. 2017;37(2-6):75-120. https://doi.org/10.1615/CritRevImmunol.v37. i2-6.10.

48. Dendrou CA, Petersen J, Rossjohn J, Fugger L. HLA variation and disease. Nat Rev Immunol. 2018;18(5):325-39. https://doi.org/10.1038/ nri.2017.143.

49. Hajeer AH, Balkhy H, Johani S, Yousef MZ, Arabi Y. Association of human leukocyte antigen class II alleles with severe Middle East respiratory syndrome-coronavirus infection. Ann Thorac Med. 2016;11(3):211-3. https://doi.org/10.4103/1817-1737.185756.

50. Xu J, Zhao S, Teng T, Abdalla AE, Zhu W, Xie L, Wang Y, Guo X. Systematic comparison of two animal-to-human transmitted human coronaviruses: SARS-CoV-2 and SARS-CoV. Viruses. 2020;12(2):244. https://doi.org/10.3390/v12020244

51. Janice Oh HL, Ken-En Gan S, Bertoletti A, Tan YJ. Understanding the T cell immune response in SARS coronavirus infection. Emerg Microbes Infect. 2012;1 (9): e23. https://doi.org/10.1038/emi.2012.26.

52. Wang SF, Chen KH, Chen M, Li WY, Chen YJ, Tsao CH, Yen MY, Huang JC, Chen YM. Human-leukocyte antigen class I CW 1502 and class II DR 0301 genotypes are associated with resistance to severe acute respiratory syndrome (SARS) infection. Viral Immunol. 2011;24(5):421-6. https://doi.org/10.1089/vim.2011.0024.

53. Lin M, Tseng HK, Trejaut JA, Lee HL, Loo JH, Chu CC, Chen PJ, Su YW, Lim KH, Tsai ZU, Lin RY, Lin RS, Huang CH. Association of HLA class I with severe acute respiratory syndrome coronavirus infection. BMC Med Genet. 2003;4:9. https://doi.org/10.1186/1471-2350-4-9.

54. Ng MH, Lau KM, Li L, Cheng SH, Chan WY, Hui PK, Zee B, Leung CB, Sung JJ. Association of human-leukocyte-antigen class I ( $\left.B^{*} 0703\right)$ and class II (DRB1*0301) genotypes with susceptibility and resistance to the development of severe acute respiratory syndrome. J Infect Dis. 2004;190(3):515-8. https://doi.org/10.1086/421523.

55. Anderson C. Dingell opens second front in Gallo war. Nature. 1991;354(6349):95. https://doi.org/10.1038/354095a0

56. Chen YM, Liang SY, Shih YP, Chen CY, Lee YM, Chang L, Jung SY, Ho MS, Liang KY, Chen HY, Chan YJ, Chu DC. Epidemiological and genetic correlates of severe acute respiratory syndrome coronavirus infection in the hospital with the highest nosocomial infection rate in Taiwan in 2003. J Clin Microbiol. 2006;44(2):359-65. https://doi.org/10.1128/ JCM.44.2.359-365.2006.

57. Ng MH, Cheng SH, Lau KM, Leung GM, Khoo US, Zee BC, Sung JJ. Immunogenetics in SARS: a case-control study. Hong Kong Med J. 2010;16(5 Suppl 4):29-33.

58. Keicho N, Itoyama S, Kashiwase K, Phi NC, Long HT, Ha LD, Ban WV, Hoa BK, Hang NT, Hijikata M, Sakurada S, Satake M, Tokunaga K, Sasazuki T, Quy T. Association of human leukocyte antigen class II alleles with severe acute respiratory syndrome in the Vietnamese population. Hum Immunol. 2009;70(7):527-31. https://doi.org/10. 1016/j.humimm.2009.05.006.
59. Li X, Geng M, Peng Y, Meng L, Lu S. Molecular immune pathogenesis and diagnosis of COVID-19. J Pharm Anal. 2020;10(2):102-8. https://doi. org/10.1016/j.jpha.2020.03.001.

60. Nicoli F, Solis-Soto MT, Paudel D, Marconi P, Gavioli R, Appay V, Caputo A. Age-related decline of de novo T cell responsiveness as a cause of COVID-19 severity. Geroscience. 2020;42(4):1015-9. https://doi.org/10. 1007/s11357-020-00217-W.

61. Ye Q, Wang B, Mao J. The pathogenesis and treatment of the 'Cytokine Storm'in COVID-19. J Infect. 2020;80(6):607-13. https://doi.org/10 1016/j.jinf.2020.03.037.

62. Mangalmurti N, Hunter CA. Cytokine storms: understanding COVID-19. Immunity. 2020;53(1):19-25. https://doi.org/10.1016/j.immuni.2020.06. 017.

63. Hill AV. Immunogenetics and genomics. Lancet. 2001;357(9273):203741. https://doi.org/10.1016/S0140-6736(00)05117-5.

64. Kangueane P, Sakharkar MK. HLA-peptide binding prediction using structural and modeling principles. Methods Mol Biol. 2007;409:293-9. https://doi.org/10.1007/978-1-60327-118-9_21.

65. Nguyen A, David JK, Maden SK, Wood MA, Weeder BR, Nellore A, Thompson RF (2020) Human leukocyte antigen susceptibility map for severe acute respiratory syndrome coronavirus 2. J Virol. 94 (13). https:// doi.org/10.1128/JVI.00510-20.

66. Galvez J, Galvez JJ, Garcia-Penarrubia P. Is TCR/pMHC affinity a good estimate of the T-cell response? An answer based on predictions from 12 phenotypic models. Front Immunol. 2019;10:349. https://doi.org/10. 3389/fimmu.2019.00349.

67. Yung YL, Cheng CK, Chan HY, Xia JT, Lau KM, Wong RSM, Wu AKL, Chu RW, Wong ACC, Chow EYD, Yip SF, Leung JNS, Lee CK, Ng MHL. Association of HLA-B22 serotype with SARS-CoV-2 susceptibility in Hong Kong Chinese patients. HLA. 2020. https://doi.org/10.1111/tan.14135.

68. Barquera R, Collen E, Di D, Buhler S, Teixeira J, Llamas B, Nunes JM, Sanchez-Mazas A. Binding affinities of 438 HLA proteins to complete proteomes of seven pandemic viruses and distributions of strongest and weakest HLA peptide binders in populations worldwide. HLA. 2020;96(3):277-98. https://doi.org/10.1111/tan.13956.

69. Neumann-Haefelin C. HLA-B27-mediated protection in HIV and hepatitis $C$ virus infection and pathogenesis in spondyloarthritis: two sides of the same coin? Curr Opin Rheumatol. 2013;25(4):426-33. https://doi. org/10.1097/BOR.0b013e328362018f.

70. Buonaguro L, Tagliamonte M, Tornesello ML, Buonaguro FM. SARSCoV-2 RNA polymerase as target for antiviral therapy. J Transl Med. 2020;18(1):185. https://doi.org/10.1186/s12967-020-02355-3.

71. Bafna K, Krug RM, Montelione GT. Structural similarity of SARS-CoV2 M(pro) and HCV NS3/4A proteases suggests new approaches for identifying existing drugs useful as COVID-19 therapeutics. ChemRxiv. 2020. https://doi.org/10.26434/chemrxiv.12153615.v1.

72. Zhang C, Shi L, Wang FS. Liver injury in COVID-19: management and challenges. Lancet Gastroenterol Hepatol. 2020;5(5):428-30. https://doi. org/10.1016/S2468-1253(20)30057-1.

73. Tan $L$, Wang Q, Zhang D, Ding J, Huang Q, Tang YQ, Wang Q, Miao H. Lymphopenia predicts disease severity of COVID-19: a descriptive and predictive study. Signal Transduct Target Ther. 2020;5(1):33. https://doi. org/10.1038/s41392-020-0148-4.

74. Kiyotani K, Toyoshima Y, Nemoto K, Nakamura Y. Bioinformatic prediction of potential T cell epitopes for SARS-Cov-2. J Hum Genet. 2020;65(7):569-75. https://doi.org/10.1038/s10038-020-0771-5.

75. Wang W, Zhang W, Zhang J, He J, Zhu F. Distribution of HLA allele frequencies in 82 Chinese individuals with coronavirus disease-2019 (COVID-19). HLA. 2020;96(2):194-6. https://doi.org/10.1111/tan.13941.

76. Wang F, Huang S, Gao R, Zhou Y, Lai C, Li Z, Xian W, Qian X, Li Z, Huang Y, Tang Q, Liu P, Chen R, Liu R, Li X, Tong X, Zhou X, Bai Y, Duan G, Zhang T, Xu X, Wang J, Yang H, Liu S, He Q, Jin X, Liu L. Initial whole-genome sequencing and analysis of the host genetic contribution to COVID-19 severity and susceptibility. Cell Discov. 2020;6(1):83. https://doi.org/10. 1038/s41421-020-00231-4.

77. Tomita Y, Ikeda T, Sato R, Sakagami T. Association between HLA gene polymorphisms and mortality of COVID-19: an in silico analysis. Immun Inflamm Dis. 2020;8(4):684-94. https://doi.org/10.1002/iid3.358.

78. Warren RL, Birol I. HLA predictions from the bronchoalveolar lavage fluid and blood samples of eight COVID-19 patients at the pandemic 
onset. Bioinformatics. 2020. https://doi.org/10.1093/bioinformatics/ btaa756.

79. Toyoshima Y, Nemoto K, Matsumoto S, Nakamura Y, Kiyotani K. SARS-COV-2 genomic variations associated with mortality rate of COVID-19. J Hum Genet. 2020;65(12):1075-82. https://doi.org/10.1038/ s10038-020-0808-9.

80. Correale P, Mutti L, Pentimalli F, Baglio G, Saladino RE, Sileri P, Giordano A. HLA-B*44 and $C^{*} 01$ prevalence correlates with Covid 19 spreading across Italy. Int J Mol Sci. 2020;21 (15):5205. https://doi.org/10.3390/ ijms21155205.

81. Simmonds MJ, Gough SC. Genetic insights into disease mechanisms of autoimmunity. Br Med Bull. 2004;71:93-113. https://doi.org/10.1093/ $\mathrm{bmb} / \mathrm{ldh} 032$.

82. Li S, Jiao H, Yu X, Strong AJ, Shao Y, Sun Y, Altfeld M, Lu Y. Human leukocyte antigen class I and class II allele frequencies and HIV-1 infection associations in a Chinese cohort. J Acquir Immune Defic Syndr. 2007;44(2):121-31. https://doi.org/10.1097/01.qai.0000248355.40877. 2a.

83. Vejbaesya S, Thongpradit R, Kalayanarooj S, Luangtrakool K, Luangtrakool P, Gibbons RV, Srinak D, Ngammthaworn S, Apisawes K, Yoon IK, Thomas SJ, Jarman RG, Srikiakthachorn A, Green S, Chandanayingyong D, Park S, Friedman J, Rothman AL, Stephens HA. HLA class I supertype associations with clinical outcome of secondary dengue virus infections in ethnic thais. J Infect Dis. 2015;212(6):939-47. https://doi.org/10. 1093/infdis/jiv127.

84. Hudson LE, Allen RL. Leukocyte Ig-like receptors-a model for MHC class I disease associations. Front Immunol. 2016;7:281. https://doi.org/ 10.3389/fimmu.2016.00281.

85. Rallon N, Restrepo C, Vicario JL, Del Romero J, Rodriguez C, Garcia-Samaniego J, Garcia M, Cabello A, Gorgolas M, Benito JM. Human leucocyte antigen (HLA)-DQB1*03:02 and HLA-A*02:01 have opposite patterns in their effects on susceptibility to HIV infection. HIV Med. 2017;18(8):58794. https://doi.org/10.1111/hiv.12494.

86. Falfan-Valencia R, Narayanankutty A, Resendiz-Hernandez JM, PerezRubio G, Ramirez-Venegas A, Nava-Quiroz KJ, Bautista-Felix NE, VargasAlarcon G, Castillejos-Lopez MDJ, Hernandez A. An increased frequency in HLA class I alleles and haplotypes suggests genetic susceptibility to influenza A (H1N1) 2009 pandemic: a case-control study. J Immunol Res. 2018;2018:3174868. https://doi.org/10.1155/2018/3174868.

87. Correale P, Saladino RE, Nardone V, Giannicola R, Agostino R, Pirtoli L, Caraglia M, Botta C, Tagliaferri P. Could PD-1/PDL1 immune checkpoints be linked to HLA signature? Immunotherapy. 2019;11(18):1523-6. https://doi.org/10.2217/imt-2019-0160.

88. Sanders PA, Thomson W, Dyer PA, Grennan DM. Haplotypes bearing HLA-A, -B, and -DR: Bf and C4 genes in rheumatoid arthritis families. Tissue Antigens. 1989;33(1):21-9. https://doi.org/10.1111/j.1399-0039. 1989.tb01673.x.

89. Orchard TR, Thiyagaraja S, Welsh KI, Wordsworth BP, Hill Gaston JS, Jewell DP. Clinical phenotype is related to HLA genotype in the peripheral arthropathies of inflammatory bowel disease. Gastroenterology. 2000;118(2):274-8. https://doi.org/10.1016/s0016-5085(00)70209-5.

90. Grams SE, Moonsamy PV, Mano C, Oksenberg JR, Begovich AB. Two new HLA-B alleles, $B * 4422$ and $B * 4704$, identified in a study of families with autoimmunity. Tissue Antigens. 2002;59(4):338-40. https://doi.org/10. 1034/j.1399-0039.2002.590417.x.

91. Ueta M, Kannabiran C, Wakamatsu TH, Kim MK, Yoon KC, Seo KY, Joo CK, Sangwan V, Rathi V, Basu S, Shamaila A, Lee HS, Yoon S, Sotozono C, Gomes JA, Tokunaga K, Kinoshita S. Trans-ethnic study confirmed independent associations of HLA-A*02:06 and HLA-B*44:03 with cold medicine-related Stevens-Johnson syndrome with severe ocular surface complications. Sci Rep. 2014;4:5981. https://doi.org/10.1038/srep0 5981.

92. Jung ES, Cheon JH, Lee JH, Park SJ, Jang HW, Chung SH, Park MH, Kim TG, Oh HB, Yang SK, Park SH, Han JY, Hong SP, Kim TI, Kim WH, Lee MG. HLA-C*01 is a risk factor for Crohn's disease. Inflamm Bowel Dis. 2016;22(4):796-806. https://doi.org/10.1097/MIB.0000000000000693.

93. Johnston DT, Mehaffey G, Thomas J, Young KR Jr, Wiener H, Li J, Go RC, Schroeder HW Jr. Increased frequency of HLA-B44 in recurrent sinopulmonary infections (RESPI). Clin Immunol. 2006;119(3):346-50. https:// doi.org/10.1016/j.clim.2006.02.001.
94. Fadda L, Korner C, Kumar S, van Teijlingen NH, Piechocka-Trocha A, Carrington M, Altfeld M. HLA-CW*0102-restricted HIV-1 p24 epitope variants can modulate the binding of the inhibitory KIR2DL2 receptor and primary NK cell function. PLoS Pathog. 2012;8(7): e1002805. https:// doi.org/10.1371/journal.ppat.1002805.

95. Mori M, Wichukchinda N, Miyahara R, Rojanawiwat A, Pathipvanich P, Miura T, Yasunami M, Ariyoshi K, Sawanpanyalert P. Impact of HLA alleleKIR pairs on disease outcome in HIV-infected Thai population. J Acquir Immune Defic Syndr. 2018;78(3):356-61. https://doi.org/10.1097/QAl. 0000000000001676.

96. Pende D, Falco M, Vitale M, Cantoni C, Vitale C, Munari E, Bertaina A, Moretta F, Del Zotto G, Pietra G, Mingari MC, Locatelli F, Moretta L. Killer Ig-like receptors (KIRs): their role in NK cell modulation and developments leading to their clinical exploitation. Front Immunol. 2019;10:1179. https://doi.org/10.3389/fimmu.2019.01179.

97. Vitale M, Cantoni C, Della Chiesa M, Ferlazzo G, Carlomagno S, Pende D, Falco M, Pessino A, Muccio L, De Maria A, Marcenaro E, Moretta L, Sivori S. An historical overview: the discovery of how NK cells can kill enemies, recruit defense troops, and more. Front Immunol. 2019;10:1415. https:// doi.org/10.3389/fimmu.2019.01415.

98. Sim MJW, Rajagopalan S, Altmann DM, Boyton RJ, Sun PD, Long EO. Human NK cell receptor KIR2DS4 detects a conserved bacterial epitope presented by HLA-C. Proc Natl Acad Sci USA. 2019;116(26):12964-73. https://doi.org/10.1073/pnas.1903781116.

99. Sakuraba A, Haider H, Sato T. Population difference in allele frequency of HLA-C*05 and its correlation with COVID-19 mortality. Viruses. 2020;12(11):1333. https://doi.org/10.3390/v12111333.

100. Littera R, Campagna M, Deidda S, Angioni G, Cipri S, Melis M, Firinu D, Santus S, Lai A, Porcella R, Lai S, Rassu S, Scioscia R, Meloni F, Schirru D, Cordeddu W, Kowalik MA, Serra M, Ragatzu P, Carta MG, Del Giacco S, Restivo A, Deidda S, Orru S, Palimodde A, Perra R, Orru G, Conti M, Balestrieri C, Serra G, Onali S, Marongiu F, Perra A, Chessa L. Human leukocyte antigen complex and other immunogenetic and clinical factors influence susceptibility or protection to SARS-CoV-2 infection and severity of the disease course. The Sardinian Exp Front Immunol. 2020;11: 605688. https://doi.org/10.3389/fimmu.2020.605688.

101. Novelli A, Andreani M, Biancolella M, Liberatoscioli L, Passarelli C, Colona VL, Rogliani P, Leonardis F, Campana A, Carsetti R, Andreoni M, Bernardini S, Novelli G, Locatelli F. HLA allele frequencies and susceptibility to COVID-19 in a group of 99 Italian patients. HLA. 2020;96(5):610-4. https://doi.org/10.1111/tan.14047.

102. Severe Covid GG, Ellinghaus D, Degenhardt F, Bujanda L, Buti M, Albillos A, Invernizzi P, Fernandez J, Prati D, Baselli G, Asselta R, Grimsrud MM, Milani C, Aziz F, Kassens J, May S, Wendorff M, Wienbrandt L, Uellendahl-Werth F, Zheng T, Yi X, de Pablo R, Chercoles AG, Palom A, Garcia-Fernandez AE, Rodriguez-Frias F, Zanella A, Bandera A, Protti A, Aghemo A, Lleo A, Biondi A, Caballero-Garralda A, Gori A, Tanck A, Carreras Nolla A, Latiano A, Fracanzani AL, Peschuck A, Julia A, Pesenti A, Voza A, Jimenez D, Mateos B, Nafria Jimenez B, Quereda C, Paccapelo C, Gassner C, Angelini C, Cea C, Solier A, Pestana D, MunizDiaz E, Sandoval E, Paraboschi EM, Navas E, Garcia Sanchez F, Ceriotti F, Martinelli-Boneschi F, Peyvandi F, Blasi F, Tellez L, Blanco-Grau A, Hemmrich-Stanisak G, Grasselli G, Costantino G, Cardamone G, Foti G, Aneli S, Kurihara H, ElAbd H, My I, Galvan-Femenia I, Martin J, Erdmann J, Ferrusquia-Acosta J, Garcia-Etxebarria K, Izquierdo-Sanchez L, Bettini LR, Sumoy L, Terranova L, Moreira L, Santoro L, Scudeller L, Mesonero F, Roade L, Ruhlemann MC, Schaefer M, Carrabba M, Riveiro-Barciela M, Figuera Basso ME, Valsecchi MG, Hernandez-Tejero M, Acosta-Herrera M, D’Angio M, Baldini M, Cazzaniga M, Schulzky M, Cecconi M, Wittig M, Ciccarelli M, Rodriguez-Gandia M, Bocciolone M, Miozzo M, Montano N, Braun N, Sacchi N, Martinez N, Ozer O, Palmieri O, Faverio P, Preatoni P, Bonfanti P, Omodei P, Tentorio P, Castro P, Rodrigues PM, Blandino Ortiz A, de Cid R, Ferrer R, Gualtierotti R, Nieto R, Goerg S, Badalamenti S, Marsal S, Matullo G, Pelusi S, Juzenas S, Aliberti S, Monzani V, Moreno V, Wesse T, Lenz TL, Pumarola T, Rimoldi V, Bosari S, Albrecht W, Peter W, Romero-Gomez M, D'Amato M, Duga S, Banales JM, Hov JR, Folseraas T, Valenti L, Franke A, Karlsen TH. Genomewide association study of severe COVID-19 with respiratory failure. N Engl J Med. 2020;383(16):1522-34. https://doi.org/10.1056/NEJMoa2020283.

103. Kachuri L, Francis SS, Morrison ML, Wendt GA, Bosse Y, Cavazos TB, Rashkin SR, Ziv E, Witte JS. The landscape of host genetic factors 
involved in immune response to common viral infections. Genome Med. 2020;12(1):93. https://doi.org/10.1186/s13073-020-00790-x.

104. Pisanti S, Deelen J, Gallina AM, Caputo M, Citro M, Abate M, Sacchi $\mathrm{N}$, Vecchione C, Martinelli R. Correlation of the two most frequent HLA haplotypes in the Italian population to the differential regional incidence of Covid-19. J Transl Med. 2020;18(1):352. https://doi.org/10 1186/s12967-020-02515-5.

105. Lorente L, Martin MM, Franco A, Barrios Y, Caceres JJ, Sole-Violan J, Perez A, Marcos YRJA, Ramos-Gomez L, Ojeda N, Jimenez A, Working Group on C-CICU, Annex. Members of the Bg. HLA genetic polymorphisms and prognosis of patients with COVID-19. Med Intensiva. 2021;45(2):96103. https://doi.org/10.1016/j.medin.2020.08.004

106. Warren RL, Birol I. Retrospective in silico HLA predictions from COVID-19 patients reveal alleles associated with disease prognosis. medRxiv. 2020 https://doi.org/10.1101/2020.10.27.20220863.

107. Gonzalez-Galarza FF, Takeshita LY, Santos EJ, Kempson F, Maia MH, da Silva AL, Teles e Silva AL, Ghattaoraya GS, Alfirevic A, Jones AR, Middleton D. Allele frequency net 2015 update: new features for HLA epitopes, KIR and disease and HLA adverse drug reaction associations. Nucleic Acids Res. 2015:43(1):784-8. https://doi.org/10.1093/nar/gku1166.

108. Li X, Xu S, Yu M, Wang K, Tao Y, Zhou Y, Shi J, Zhou M, Wu B, Yang Z, Zhang C, Yue J, Zhang Z, Renz H, Liu X, Xie J, Xie M, Zhao J. Risk factors for severity and mortality in adult COVID-19 inpatients in Wuhan. Allergy Clin Immunol. 2020;146(1):110-8. https://doi.org/10.1016/j.jaci. 2020.04.006.
109. Jain V, Yuan JM. Predictive symptoms and comorbidities for severe COVID-19 and intensive care unit admission: a systematic review and meta-analysis. Int J Public Health. 2020;65(5):533-46. https://doi.org/10. 1007/s00038-020-01390-7.

110. Yang X, Yu Y, Xu J, Shu H, Xia J, Liu H, Wu Y, Zhang L, Yu Z, Fang M, Yu T, Wang Y, Pan S, Zou X, Yuan S, Shang Y. Clinical course and outcomes of critically ill patients with SARS-CoV-2 pneumonia in Wuhan, China: a single-centered, retrospective, observational study. Lancet Respir Med. 2020;8(5):475-81. https://doi.org/10.1016/S2213-2600(20)30079-5.

111. Guan WJ, Liang WH, Zhao Y, Liang HR, Chen ZS, Li YM, Liu XQ, Chen RC, Tang CL, Wang T, Ou CQ, Li L, Chen PY, Sang L, Wang W, Li JF, Li CC, Ou LM, Cheng B, Xiong S, Ni ZY, Xiang J, Hu Y, Liu L, Shan H, Lei CL, Peng YX, Wei L, Liu Y, Hu YH, Peng P, Wang JM, Liu JY, Chen Z, Li G, Zheng ZJ, Qiu SQ, Luo J, Ye CJ, Zhu SY, Cheng LL, Ye F, Li SY, Zheng JP, Zhang NF, Zhong NS, He JX, China Medical Treatment Expert Group for C. Comorbidity and its impact on 1590 patients with COVID-19 in China: a nationwide analysis. Eur Respir J. 2020;55(5):2000547. https://doi.org/10 1183/13993003.00547-2020

\section{Publisher's Note}

Springer Nature remains neutral with regard to jurisdictional claims in published maps and institutional affiliations.
Ready to submit your research? Choose BMC and benefit from:

- fast, convenient online submission

- thorough peer review by experienced researchers in your field

- rapid publication on acceptance

- support for research data, including large and complex data types

- gold Open Access which fosters wider collaboration and increased citations

- maximum visibility for your research: over 100M website views per year

At BMC, research is always in progress.

Learn more biomedcentral.com/submissions 